\section{Semenov A., Kozhushko G., Sakhno T.}

\title{
INFLUENCE OF UV RADIATION IN PRE-SOWING TREATMENT OF SEEDS OF CROPS
}

Об’єктом дослідження є насіння сільськогосподарських культур: пшениці, ячменю, ріпаку та моркви. В роботі досліджували вплив ультрафіолетового (УФ) випромінювання на насіння сількогосподарських культур в передпосівній обробці (енергія проростання та схожість), що направлено на вирішення проблеми агропромислового комплексу, а саме збільшення кількості та якості врожаю. При проведенні експериментальних робіт використовували ультрафіолетові розрядні лампи низького тиску, в яких максимум випромінювання припадає на 254 нм. Для вимірювання доз УФ-опромінення використовували радіометр «Тензор-31» (Україна), що забезпечує вимірювання в діапазоні довжин хвиль $200-400$ нм. Результати дослідження ростових прочесів (енергї проростання та схожості) показали, що для насіння

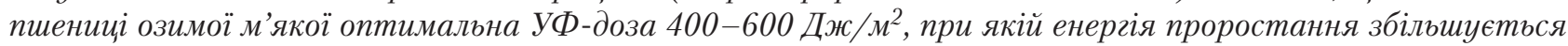
на 7-12\%, а схожість на 9-15\%. Для ячменю озимого оптимальна доза - 250 Дж/м², при якій схожість

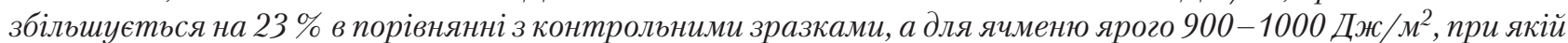
збільшення схожості - 80 \%. При опроміненні насіння ріпаку максимум показників енергї проростання та

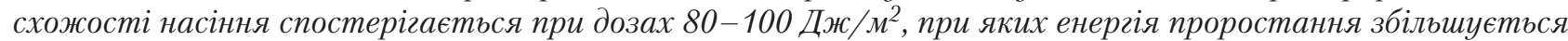
на 20-26\% а схожість на $16 \%$. При порівнянні впливу на насіння ріпаку різних спектральних областей УФ-діапазону 200-400 нм відзначили збільшення енергї проростання та схожості на 6-9\% для області С. При обробиі насіння моркви встановили, що УФ-опромінення стимулює ростові процеси: схожість насіння

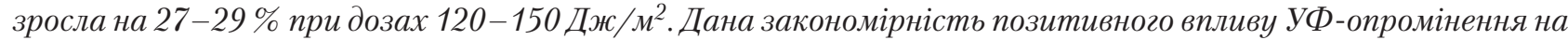
ростові процеси сільгоспкультур спостерігається в процесі зростання, що сприяє збільшенню врожайності.

Ключові слова: УФ-опромінення, доза опромінення, передпосівна обробка насіння, схожість та енергія проростання.

\section{Introduction}

Ensuring high yield of agricultural crops is an important task of the agro-industrial complex in the near future. To solve this problem, specialists improve and develop new agro-measures aimed at improving the quality of seed material and yield [1,2]. In modern conditions, in order to improve the sowing qualities of seeds, physical methods are used to bring their biological systems out of rest [3]. Known studies in which the influence of weak physical factors, such as ultrasound, led to the stimulation of yield and improve product quality [4]. The physical factors influencing the seed include the influence of X-ray [5], ultraviolet (UV) [6], optical and infrared radiation [7]. The spectral composition of radiation and its intensity affect the physiological processes in the pre-sowing treatment of seed material and in the process of plant development and growth. A large number of experimental studies are devoted to this problem $[8,9]$. Most studies in this direction refer to the visible region of the emission spectrum from $400 \mathrm{~nm}$ to $710 \mathrm{~nm}$ [10]. The relevance of the work is determined by the search and development of technologies for obtaining effective physical biostimulants for pre-sowing treatment of seeds, contribute to the improvement of sowing qualities, enhancement of photosynthetic activity, survival and yield [3]. The object of research is the seeds of crops: wheat, barley, rapeseed and carrots. The aim of research is determination of the pre-sowing effect of UV irradiation of the object of research on biological processes - germination energy and germination capacity in laboratory conditions.

\section{Methods of research}

The germination energy and germination capacity of the seeds of crops are determined under laboratory conditions in accordance with the method [11]. Samples for research are taken from the batch of seed in accordance with the requirements [11]. For experimental studies, 200 seeds for the control sample and 200 grains each for UV exposure of one of the doses in the range from 50 to $3000 \mathrm{~J}^{2}$ are deducted from the obtained samples. Seeds before UV irradiation, according to the method [11], are decomposed into several layers of moistened filter paper in Petri dishes and kept in a thermostat at a temperature of $7 \pm 2{ }^{\circ} \mathrm{C}$ for 24 hours. Then, seed samples, except for the control ones, are irradiated a low-pressure mercury lamp emitting in the UV region C. During the experimental studies, lowpressure discharge UV lamps [12] are used, having a power of one arc length $(1-2 \mathrm{~W} / \mathrm{cm})$, characterized by are given in Table 1.

Table 1

Characteristics of quartz glass lamp

Jiangyin Feiyang Instrument Co., Ltd. (China)

\begin{tabular}{|c|c|c|c|c|}
\hline Lamp type & $P, \mathrm{~W}$ & $I, \mathrm{~mA}$ & $U, \mathrm{~V}$ & $\begin{array}{c}\text { UV irradiation at a dis- } \\
\text { tance of } 1 \mathrm{~m}, \mathrm{~W} / \mathrm{cm}^{2}\end{array}$ \\
\hline ZW80D19W-846 & 80 & $800-1200$ & 120 & $240-270$ \\
\hline ZW37D15W-793 & 37 & 350 & $78-101$ & 110 \\
\hline ZW23D15W-436 & 23 & 420 & $40-55$ & $62-69$ \\
\hline
\end{tabular}


The distance from the source of UV radiation with seed samples is $250 \mathrm{~mm}$. Measurement of the UV-C radiation dose is performed using a Tenzor-31 radiometer (Ukraine) using the technique [13]. The setup for presowing seed irradiation is the same as in [14]. The irradiated and control samples of seeds of agricultural crops are germinated under laboratory conditions in Petri dishes at an air temperature of $24 \pm 2{ }^{\circ} \mathrm{C}$. The obtained values for irradiated seeds by UV radiation are compared with control samples without irradiation.

\section{Research results and discussion}

Samples of soft winter wheat and winter and spring barley for research are presented by the laboratory of grain crops of Ustytim experimental plant growing station (Ustymivka, Poltava region, Ukraine). Wheat samples are investigated: No. 1 - Podolianka (UDS02111), No. 2 - Taras (UDS05054), No. 3 - Astra (UDS04766), No. 4 - Yuzhanka (UDS04779) harvest 2018 after UV irradiation with doses of 50, 120, $500,1000 \mathrm{~J} / \mathrm{m}^{2}$ (Fig. 1, a). From the presented dependence (Fig. 1, $a$ ) of the germination capacity to the dose of UV irradiation, it is determined that the optimal dose for irradiating wheat seeds is $400-600 \mathrm{~J} / \mathrm{m}^{2}$, at which the number of germinated seeds is maximum. Doses close to $1000 \mathrm{~J} / \mathrm{m}^{2}$ and more cause a decline in these indicators. The results of studies of germination and germination of wheat seeds of various varieties with a dose of UV-C exposure of $500 \mathrm{~J} / \mathrm{m}^{2}$ show that germination energy increases compared with control samples by $7-12 \%$, and germination capacity by $9-15 \%$ [15]. Samples of barley are also investigated: No. 1 - Zymovyi (var. Pallidum) winter (UKR), No. 2 Osnova (var. Pallidum) winter (UKR), No. 3 - Rytsar (var. Submedicum) spring (RUS), No. 4 - Vzirets (var. Nutans spring (UKR) reproduction of 2018 after UV irradiation with doses of $50,250,1000,3000 \mathrm{~J} / \mathrm{m}^{2}$ (Fig. 1, b). The results of studies of germination energy and germination capacity of barley seeds of different varieties show that the germination capacity for winter barley with UV doses of $250 \mathrm{~J} / \mathrm{m}^{2}$ increases by $23 \%$ compared with control samples (Fig. 1, a). And the germination capacity for spring barley at doses of $900-1000 \mathrm{~J} / \mathrm{m}^{2}$ in $80 \%$ (Fig. $1, b$ ).

The samples of rape are investigated and irradiated with doses of $50,120,240 \mathrm{~J} / \mathrm{m}^{2}$. The research results of seed germination energy as a function of the dose of UV-C irradiation show (Fig. 2, a) that with doses of large $80-100 \mathrm{~J} / \mathrm{m}^{2}$, the germination energy increases compared with the control sample by $20-26 \%$, and the germination capacity $16 \%$, and for genetically modified seed plants - the germination capacity decreased by $7-10 \%$ [16]. A decrease in the «activity» of the germination of rapeseed is also observed when irradiated with higher doses of $240 \mathrm{~J} / \mathrm{m}^{2}$ (Fig. 2, a). This pattern of «activity» of seeds after UV irradiation is observed more pronounced in the process of plant growth, their terrestrial part [17]. Samples of carrots are investigated: 1 - Perfection; 2 - Shantane Royal; 3 - Dolianka; 4 Jaskrava; 5 - Nantska after UV irradiation with doses of $120,200,500,1000 \mathrm{~J} / \mathrm{m}^{2}$. The experimental results showed that the UV irradiation of carrot seeds of all the studied varieties results in active stimulation of growth processes at a dose of $120 \mathrm{~J} / \mathrm{m}^{2}$ (Fig. 2, $b$ ). The dose of UV irradiation of $120-150 \mathrm{~J} / \mathrm{m}^{2}$ can be determined as the most optimal, at which the percentage of germination of carrot seeds has the maximum value for all studied varieties. The greatest increase in germination capacity (the difference between the irradiated and the control sample) is $57 \%$ for the variety Dolianka, the same growth $-27-29 \%$ is shown by the varieties Shantane Royal and Nantska. At radiation doses of more than $200-250 \mathrm{~J} / \mathrm{m}^{2}$, a decrease in the studied parameters is observed.
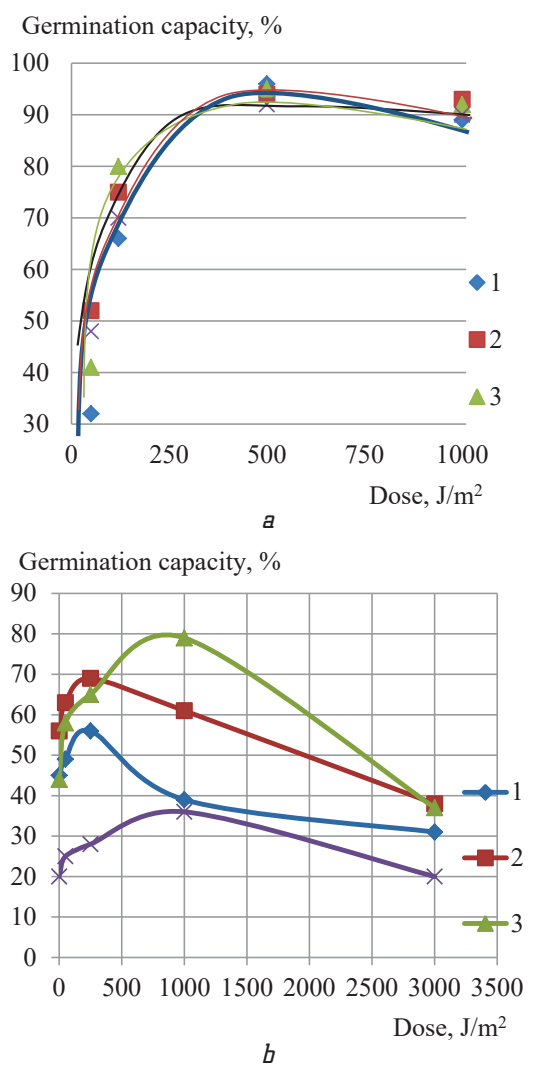

Fig. 1. Germination energy and seed germination: $a$ - wheat samples No. 1, 2, 3, 4; $b$ - barley samples No. 1, 2, 3, 4
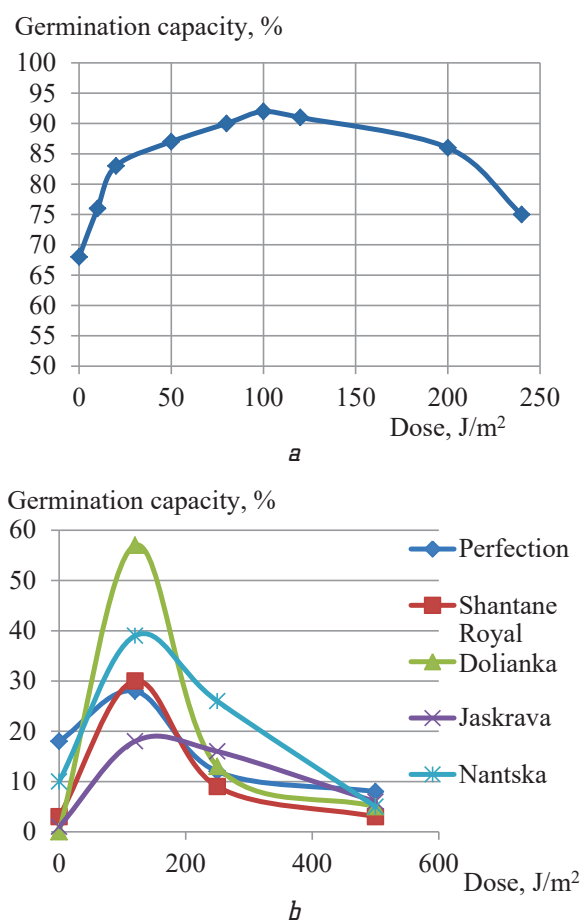

Fig. 2. Germination dependence on irradiation dose: $a$ - rapeseed; $b$ - carrots 
These results are confirmed in the field, namely, irradiated samples of carrot seeds $\mathrm{UV}-\mathrm{C}$ with a dose of $120 \mathrm{~J} / \mathrm{m}^{2}$ came down, compared with the control, earlier by 9 days. At the same time, the number of germinated seeds is $43 \%$ higher, compared with the control samples. In the process of growth, a more healthy development of the plants of irradiated seeds is noted, which influenced the increase in yield.

\section{Conclusions}

Studies have shown that UV irradiation stimulates growth processes (germination energy and germination capacity) the seeds of the studied crops. For winter soft wheat, the optimal UV dose in the pre-sowing treatment is $400-600 \mathrm{~J} / \mathrm{m}^{2}$, at which the energy of the pier increases by $7 \%$, the germination capacity by $9 \%$. For winter barley, the optimal UV dose is $250 \mathrm{~J} / \mathrm{m}^{2}$, in which the germination capacity grows by $23 \%$, and for spring barley, the UV dose is $900-1000 \mathrm{~J} / \mathrm{m}^{2}$, in which germination capacity increases by $80 \%$. For rapeseed, the maximum indicators of germination energy and seed germination are observed at doses of $80-100 \mathrm{~J} / \mathrm{m}^{2}$, at which the germination energy increases by $20 \%$, and germination capacity by $16 \%$. For carrots, doses of $120-150 \mathrm{~J} / \mathrm{m}^{2}$, at which germination capacity increases by $27 \%$. When comparing the effect on rapeseeds of different spectral regions of the UV range of $200-400 \mathrm{~nm}$, an increase in germination energy and germination capacity by $6-9 \%$ for area $C$ is noted. This pattern of positive effect of UV irradiation on the growth processes of crops is observed in the field when growing rapeseed and carrots, which contributes to an increase in yield. Pre-sowing irradiation of seeds with ultraviolet in the area of C (200-280 $\mathrm{nm})$ can find practical use in growing plants without the use of chemicals and growth stimulants.

\section{References}

1. Rifna E. J., Ratish Ramanan K., Mahendran R. Emerging technology applications for improving seed germination // Trends in Food Science \& Technology. 2019. Vol. 86. P. 95-108. doi: http:// doi.org/10.1016/j.tifs.2019.02.029

2. Shapar L. V. Nasinnieva produktyvnist sortiv ripaku ozymoho zalezhno vid strokiv sivby ta norm vysivu $\mathrm{v}$ umovakh pivdennoho stepu Ukrainy: PhD theses. Kherson, 2017. 219 p.

3. Physical Methods for Seed Invigoration: Advantages and Challenges in Seed Technology / Araújo S. de S. et. al. // Frontiers in Plant Science. 2016. Vol. 7. doi: http://doi.org/10.3389/ fpls.2016.00646

4. Enhancing seed germination of four crop species using an ultrasonic technique / Goussous S. J. et. al. // Experimental Agriculture. 2010. Vol. 46, Issue 2. P. 231-242. doi: http:// doi.org/10.1017/s0014479709991062

5. Bessonova L. A., Kamenir E. A. Pogloshhenie rentgenovskogo izlucheniya obolochkami semyan pshenitsy // Fiziologiya i biokhimiya kul'turnykh rasteniy. 1991. Vol. 23, Issue 6. P. 582-588.
6. Savel'ev V. A. Obrabotka semyan pshenitsy ul'trafioletovymi luchami // Vestnik sel'skokhozyaystvennoy nauki. 1990. Vol. 3. P. $133-135$

7. Gadzhimusieva N. T., Asvarova T. A., Abdulaeva A. S. Effekt vozdeystviya infrakrasnogo i lazernogo izlucheniya na vskhozhest' semyan pshenitsy // Fundamental'nye issledovaniya. 2014. Vol. 11, Issue 9. P. 1939-1943.

8. Tykhomyrov A. A., Sharupych V. P., Lysovskyi H. M. Svetokultura rastenyi. Novosybyrsk: Yzd-vo Sybyrskoho otdelenyia Rossyiskoi Akademyy Nauk, 2000. 213 p.

9. Chervinskyi L. S., Romanenko O. I. Vymohy do spektralnoho skladu shtuchnykh dzherel optychnoho vyprominiuvannia dlia vyroshchuvannia roslyn u sporudakh zakrytoho hruntu // Enerhetyka i avtomatyka. 2016. Issue 3. P. 88-95.

10. Zhukova T. A. Vliyanie dliny volny lazernogo izlucheniya na effektivnost' prorastaniya semyan i formirovanie rostka pshenitsy // Agrarnaya nauka v usloviyakh modernizatsii i innovatsionnogo razvitiya. 2017. P. 82-84.

11. DSTU 4138-2002. Nasinnia silskohospodarskykh kultur. Metody vyznachennia yakosti. Kyiv, 2003. 173 p.

12. Semenov A. O., Kozhushko H. M., Balia L. V. Non-ozone germicidal lamps for units of photochemical and photobiological action // Technology Audit and Production Reserves. 2015. Vol. 4, Issue 1 (24). P. 4-7. doi: http://doi.org/10.15587/ 2312-8372.2015.46953

13. MVU 11-038-2007. Dzherela ultrafioletovoho vyprominiuvannia: metodyka vykonannia vymiriuvan parametriv ultrafioletovoho vyprominiuvannia. Kharkiv: NNTs «Instytut metrolohiiiu», 2007. 33 p.

14. Semenov A. O., Kozhushko H. M., Sakhno T. V. Effects of preventive UV-inflammation on the development and productivity of potatoes // Bulletin of Poltava State Agrarian Academy. 2018. Issue 1. P. 18-22. doi: http://doi.org/10.31210/ visnyk.2018.01.02

15. Influence of ultraviolet radiation on germination, sprouting and growth processes of wheat / Semenov A. O. et. al. // Bulletin of Poltava State Agrarian Academy. 2018. Issue 4. P. 70-75. doi: http://doi.org/10.31210/visnyk2018.04.10

16. Semenov A. O., Kozhushko H. M., Sakhno T. V. Efficiency of germination of seeds in pre-sowing irradiation by its UV radiation of different spectral composition // Bulletin of Poltava State Agrarian Academy. 2018. Issue 3. P. 27-31. doi: http:// doi.org/10.31210/visnyk2018.03.04

17. Semenov A., Kozhushko G., Sakhno T. Influence of pre-sowing UV-radiation on the energy of germination capacity and germination ability of rapeseed // Technology Audit and Production Reserves. 2018. Vol. 5, Issue 1 (43). P. 61-65. doi: http:// doi.org/10.15587/2312-8372.2018.143417

Semenov Anatoly, PhD, Associate Professor, Department of Commodity Studies, Biotechnology, Expertise and Customs, Poltava University of Economics and Trade, Ukraine, e-mail: asemen2015@gmail.com, ORCID: http://orcid.org/0000-0003-3184-6925

Kozhushko Gregory, Doctor of Technical Sciences, Professor, Department of Commodity Studies, Biotechnology, Expertise and Customs, Poltava University of Economics and Trade, Ukraine, ORCID: http:// orcid.org/0000-0002-7306-4529

Sakhno Tamara, Doctor of Chemical Sciences, Professor, Department of Commodity Studies, Biotechnology, Expertise and Customs, Poltava University of Economics and Trade, Ukraine, e-mail: sakhno2001@gmail.com, ORCID: http://orcid.org/0000-0001-7049-4657 